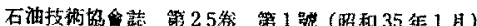

JOURNAL OF THE JAPANESE ASSOCIATION OF PETROLEUM TECHNOLOGISTS

VOL. 25. NO. 1 (January, 1960)

\title{
2 次回収の計画に対する基礎知識
}

\author{
藤 井 清 光*

\section{Fundamental Knowledges for Planning Secondary Recovery} \\ By \\ Kiyomitsu FUJII

\begin{abstract}
For the purpose of obtaining a successful result of secondary recovery method it needs a detailed plan for the project. Fundamental knowledges for planning the method, including a reservoir study carried out by the use of decline curves, are described in this paper.
\end{abstract}

\section{I. 計画に対して考えるべきこと}

わが国の油出で行われた多くの2次回収のなかには、 非常によい成續を上げたものがある半面，全く失敗に終 つたものるある。それらについて調べてみると，成杪し たもののなかには油層の条件が元来よいものむあるが， 計画がよかつたためによい結果になつたものがある。 逆に，かなりよい条件の油層で市りながら，計画が不適 当であつたために，失敗したものもある。このよ5に， 2 次回収を成功させるためには，綿密な計画を立ててこ れを奏行することが最も重要なこととなる。

2炎回収の計画は次の顼字に上つて行放る。

(1) 油層の調香

(2) 2 次回収の種類の決定

(3) 作業計画を立てること

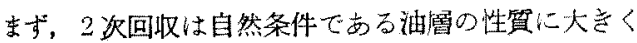
支配される。それてここれついて充分に調查する。そし て油層に適した 2 次回収の方法を洪定する。次に油廨の 住賀に応じた作業計画を立てる。作業計画を立てる埸台 には，次の項目について考慮する。

(1) 注入する流体の種類と埋

(2) 掘るべき护韭の数，配置，その時其

(3) 拃下からの産出量(時間の経過による)

(4) 現在ある採油扑儿対する优㯰

(5) 地上設嘈一注入流体の処理装置

以下にはまず，一般の 2 次回収に対する油㬝の調查に
いてて記し，次には备回収法の計画に対吉る基礎知識一 いて記す。後者に対しては，加が国の現状では，2次 回収のなかでもガス理入と水攻法が主体をなしているの で、书むにこれにつ、て即す。

\section{2 次回収に対する油層の調査}

\section{1.調查の種類}

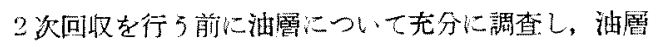
の状熊を正確に知らなければならないこ机に基づい て, 最も適した 2 次回収の方法を計画する。調查項目に は次のよ弓なものがある。

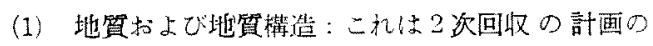
基礎になる。特に油曆の分布状態を明らかにする必要が あ。

(2) 深さ：油尿の分布状態が明らかけなれば，深ざ

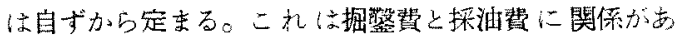

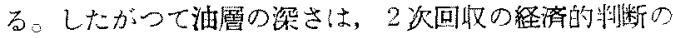

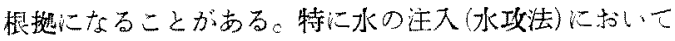

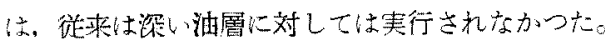

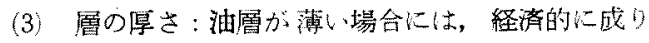
たたない。それで油層はなるべ厚いものがよい。厤が

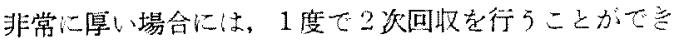
ないのて，2段にわけて行放なければならない。しかし

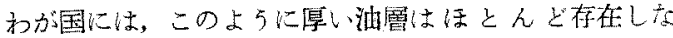
b.

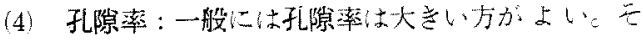
れは油の理威量が大をくなる可能性があるからでする 


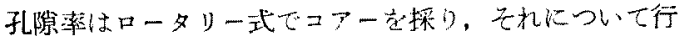
らのが普通である，孔陌荳の測定には非常に誤差が入り やすいので，充分な注意が必要である。

５）流体の飽和率：油層の孔妳に存在寸る流体の飽 和率は，2次回収の成功のいかんに浑い関俰が击る。油 の飽和率㵝高いほとよい。これが低いと2次回收の成功 の可能性は少ない。ガス王入を行う場合には，ガスの飽 和率が低いことを必要とする。ガスの飽和率が高いと， ガスが油を押さないて流れるからである。水攻法を行ら 壦合には，水の飽和率が低いこと老必要と寸る。水の飽 和韧が高いと，水が油を押さないで流れるからである。

(6) 油の埋蔵量：油の埋蔵量は(油屬の体稆) $\times$ (孔隙

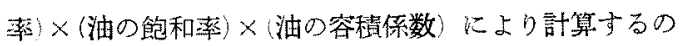
が 1 方法である。油の埋藏量は大きいほど経済的に有利 である。

（7）透率：澺透䔞が小さすぎると，流体(特に水) が入りにくいので, 有利でない。港唀は油層全体にわ

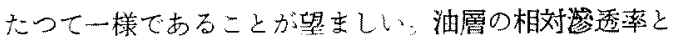
しては，油に対するものはなるべく大きく，ガスに対方 るもの，拉さび水に対するものはなるべく小さいことが 望李しい。

(8)‘流体の流れ関する油層の速続性：油層のなか には、流体の流れを遮䉼するものがあつてはよくない。

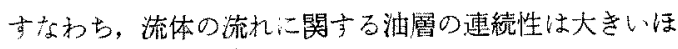
とよい。

(9)流体の性質：油の粘性汃高いと，特に水攻法が 奉行しにくくなる，粘性の高い油は，火攻法に対しては さしつか充ない。油層に含まれている水のイオンが時に 作業儿関倸する。すな放ち，水が波澱しやすい物質を含 んでいるか，または水か腐触性をむつているか等も見落 してはならないことである。

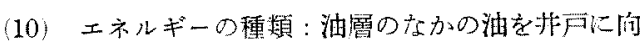
かつて流すエネルギーとしては，ガス・水および雷力が 古るっこのエネルギーの種䫏は2次回収の種類の決定に 関倸することがある。一般に水押し型の油㕌は水攻法に 適しない,ガスキャップの存在む水攻法に適しない。

(11) 油層岩の成分：油層江含まれている粘土鈗物は 水て接触して膨瀾することがあるっこのことは油尿のな かの流体の流れに対して抵坑になる，机で水攻法を行 万塨合には，油層岩のなかの粘土鉱物の種䫏および量に つ、て,予め調バなければならない。

(12）開発経過：备护戸の記録に基づき，2次回収の 対象となる油畨企体の開発経渦について調べる。開発経 過として必要な記睩は，油層の圧力および各流体（油・ ガス・水）の库出量が执むなるのである。これより油層 のエネルギーの種類, ガスの存在状態, 水の侵入状態,
皮戸の故蹱の程度，油の採収可能埋蔵量などを知ること がでるるこれより2次回収の赛行方法を具体的に決定 することができる。

（13）採油丰の状態：現在ある採油护の状態は2 次回 収の作業に直接関係する。特に必要なものはケーシン グの配置，孔明管の位置，行われた水止めの状態，採油 上の障害の程度などである。

\section{2. 調查方法}

油層の状態を知るには，次の記すような方法を行う。

（1）各種の口ッグによる判断：測定記録があれば， なるべく多くの種類のものを使用する。古い井戸で，正 確な記録のないものには，放射能の測定が適している。

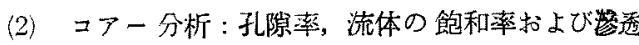
率がコアー分析の最も重要なものである。水攻法を行 場合には，粘土鉱物の性貿について調べる必要がある。

（3）流体の試娩：油層に含まれている油・ガス拈よ び水の性筫について跔駼する。

（4）油層の状態の判断：これには油層が開発されて からの総ての油層の王加の記録，各種流体の座出量の記 録を用うる。

(5) 過去の作業記録による湅断：これには仕上げ方 法, 水止め方法, 採油に関する障害, 㭾り下げ等の記録 を用うる。

(6) 試䝂的の注入：2次回收の成功のいかんを最終 的に楋断する方法として，試験的に流体を注入する方法 がある。

\section{3. 減退曲線!よる調査}

採油排より産出する油の量は，時間の経過とともに一 般に減退寸るっこれい減退曲線といわれる。この曲線は 油圈の物理的性筫，特に透率・压力・油の粘性・油の 飽和萃などの影噺を強くうける”。したがつて多くの採 油开の娍退䌷線を比較することにより，油層の全般的性 質を知ることができる゙っっこれの要点を記し，2次回収 の計画に応用すれば次の上らになる。

（1）流体の流れに関して連続した油層に存在する操 油师の油の産出減退曲線を片対数グラフ（産出量を刘数 目盛にとる）に記すと，油㬝の物理的性壁が不均一であ つても，甾曲線は平行になる。このことより油層の流体 の流机炕関する捙続性を知ることができる。2次回収の 計画においては，注大した流体が流れる籍困を知ること が最初に必要になる。上の方法により連続性を知れば, 確実な計画を立てることができる。

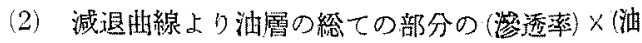
層の厚さ）の值の分布状態を知ることができる。このこ とは注大北㧍よび探油非の配置をきめるのに役立つ。

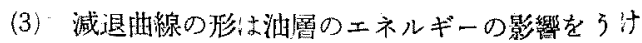


る。このことより採用すべき 2 次回収の種類を決定する ことができる。さらに油盾において，部分的に作用寸る エネルギーが異なる場合には，それに応じて注入井およ び探油许の位置を有効に決定することができる。

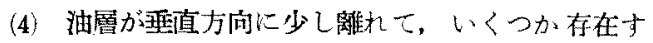
る場合には，減退的線を分析することにより，备層を別 々に評価することができる。2次回収は必ず層ごとに行 わなければならない。かが国の古い油田では，1本の採 油弗によつて，いくつかの油層を同時に採油している例

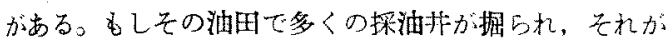
少しずつ掘り下げしているような場合には，減退帅線を 使用して，油層の存在位置，油層の大佮の性質，油層の 㹡がりの程度などを知ることができる。このことは2次 回収の計画を立てる埸合に非常に役立つ。

(5) 減退旧線の形力口, 油畨の2 次回取に対する成功 の可能性を推定することができる。例之ば，相線全体が 一定の傾向で咸退しているものより，急に折れ朋つたも のを多く含む油層の方が，2次回収に対しては有利であ る。

(6)一般減退曲線より採収可能性を計算すること ができるので，2次回収の実抑の経济的判断をすること ができる。

以上のように滅退曲線は2 次回収の計画に有効に利用 される。たたし点としては，ある程度開発された油層 てないと減退状態がわからないとである。しかし構造 の似た油田では，かなり似た减退状態を示すことがあ 节それで一般の油田飞ついて研究することは，特定の 油田の状態を嵝断するのに非常に役立つ。かが国の油田 の減退曲線については，発表されたものがある゙。

\section{III. ガス圧入の計画に対する基礎知識}

油層に対して行われるガス压入としては，正打の回澓 (pressure restoration); 压打の維持 (pressure maintenanee) およびガス押し (gas drive) の3つが行われる。こ のうち，現在のわが国で実施が考党られるのは，後の2 つであるのでこれについて記す。

\section{1. 压力の維持}

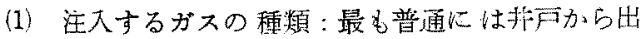
た天然ガスが用いられる。天然ガスはガソリンブラント 支通つて重い炭化水素は除か扎，大部分はメタンとな

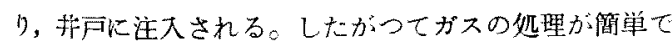
sto

(2)括戸の数：これは油尿の大きさに関係する。注 入井の数は他の 2 次回収の方法に較べると非常に少な い。一番少ない場合は1本でよい。その位硻は油層棈造 の一番高い点にきめるのが普通である。油層の大きさと

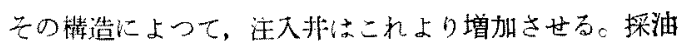
井の数は最も経済的になるように決定すればよい。こ のためには扑可のスベーシングの理論基つくくのがよ い、採油非の配置は普通の油田の開発の方法を採用し てよい。ただし注人据と採油州の間の距誰を余り近つけ ないよ5にするのがよい:ガスの注入を始める時期は， 油由が開発されてから後なるぶく早い力がよい。

(3) 奏施後の問題点：この方法で一番問題になるの

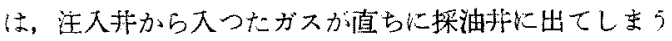
ことである。このことが発生する原因を記すならぱ，次 のよ5になる。

a. 油居に接してガス層がある場合。そのガス層が注 入されたガスの通路になつて，ガスが采油排に流れる。 このよ5な場合には，注大韭においてセメントなどを側 用して，ガス層をふさぐことが必要である。

b. 振油非がガスキャップの近くにある場合。ガスキ ナッブが存在する時には、開発が進むに良つて、そのガ スキヤップは㹡がる傾向となる。去のためにガスが採油 半に流れる。これを防ぐためには，ガスキャップの存在 寸石油層では，ガスキャップの近くに採油扑を作らない ことが必要でおる。

c. 油尿の唀率が場所によつて暴なる場合。流れの 抵抗が小さいために，济透率の大きい部分の油がガスに よつて筧に押し出される。その後はそこががスの通路に なる。したがつてこのことはガスを主入し始めた当時 には起ることが少なく、開発が進子、油が産出されるに 往つて起りやすくなる。これを防ぐ方法は実際には非常 に難しいのではあるが，粘性の高い油をガス油比の高く なつた採泊州に效して押しこむことは，比較的上い結果 となる。

d：油の飽和率が低くなつた場合。油層の開発が谁む に伦つて，油の飽和率は低くなる。乙のため油に対する

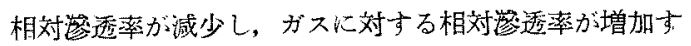

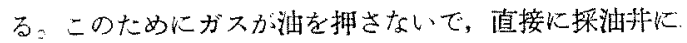
流れる。油層が虫くなると，ど5してもこの上5なこと が発生古るので、これを防ぐことはできない。この时期: になればガスの注入をやめるべきである。

\section{2. ガス押し}

ガ大押しの言画におい、て，最も問題となるのは护芦の。

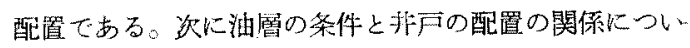

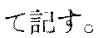

(1) 傾斜の急な權造では，構造の高い所に注大扑を 配置し，低い所に採油朴を配置する。

（2）油居が水平な時には，注大夰と採油北を交互心 配置することができる。

(3) 模造の低い所にある油を上に押しヒげる月的の 
場合には，低い所に注入非を配值する。

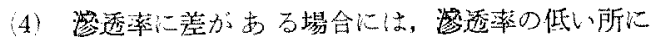

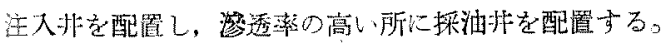

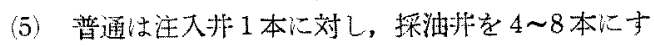

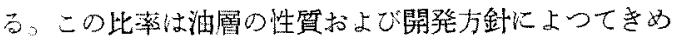
bौb。

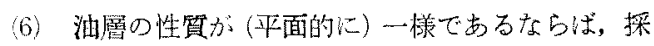
泪此をなるべく一様に分布する。

(7) ガスが油を押さないで，探油扑に現われるよ5 な时には，この注入装を採油抹に変光，他の場所に注入 筷を配置する。

8）水の库出の多い所には注入扑を配置しない。

\section{IV. 水攻法の計画に対する基礎知識}

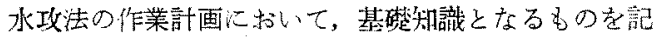

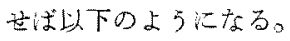

(1) 試駼時代の非F数：油層の性筫によつて，水攻 法汇適するすのと，啇さないるのとがある。それで初め て水攻法を行う場合には，少ない北户数で試験を行う。 それは次のような順序による。

\begin{tabular}{|c|c|c|}
\hline 種数 & $\begin{array}{ll}\text { 注入井 } \\
\text { 数 }\end{array}$ & 的 \\
\hline 洼入弑歌 & 1 & 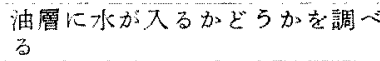 \\
\hline pilot test & 3 & 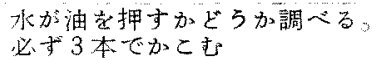 \\
\hline 㗅分的水攻法 & $4 \sim 7$ & 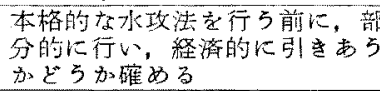 \\
\hline
\end{tabular}

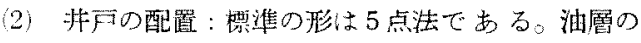
面皘が大きくない場合には，注大菲を周囲に配置する。 かかなり大きな傾斜をしている場合には，掅造の下側に注 大来を配置する。

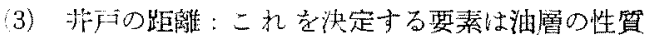
乙開発期間である。落遥率が小さい場合には距離を小さ くする。開発期間短かくするためには，距解を小さく 主る。しかし注入拃々採油扑の距磪が小さすきると，水 が值線的に進友，㹨い区域の油しか掤さないとい5欠点 bे

(4) 水の旺力: 注入する水の日扎油層の遥透率,

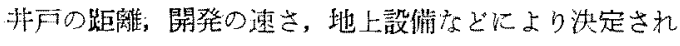

る。一般的には（注大州と探油非の間がかなり陔れてい る場合）E才が高い方が，油の回取率は高い。しかし王 扐が高すぎると地層が破壊されるので，注意要する， 破壊生力は一般に深さ $1 \mathrm{~m}$ 当り $0.12 \sim 0.35 \mathrm{~kg} / \mathrm{cm}^{2}$ て ある。

（5）水の注入量：油を押し出すために必要な水の量 は，一般に油雷の孔腺の量の1〜1.5倍である。必要な 水の量を短日の注入量で割ることにより，水攻法の期閎 がきられる。これは8〜10年以上にならないよ5にす る。

（6）油の座出量：琵想的に油が水により捧し出され れば，油層の孔腺に残る油は20〜30\%にをで下る。し かし䒠際には，このよ5に能率よく回収されることは少 ないと考えられるので, 残留率をこれ以上として，将来 の油の座出量の尒想を立てるべさである。

（7）水の供給方法・処理方法：一定量の水が 1 年中 確実に供給されなければならない。一般に油層より出る 水が最も適している。この水が足りない時には川の水,

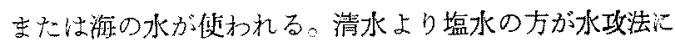
は適している。水が鉄管を腐蝕させたり，油層のなかで 沈澱物を生じたりする場合には，水の処理を行放なけれ ばならない。

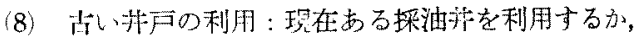
または新しく来戸を掘るかは，経費によつてきまる。 が国では採油护が多すぎるのでまずこれを利用するこ

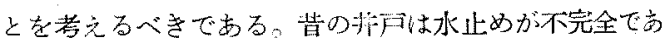
り，かつ多くの油蟹を同時に採沮したことがあるので，

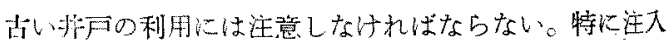
泋は完全な㣺戸であることを必要とする。

\section{参考文献}

1) 藤戈清光: Fundamental Properties of Decline Curve, 石技誌, Vol. 18, No. 6, 1953. Vol. 19, No. 2, 1954.

2) 藤井清光：Application of Theory of Decline Curve to Oil Field Exploitation, 石技誌, Vol. 24, No. 2, 1959.

3) 藤井清光: bが国の油旺の石油磨出の減退曲線, 石技誌, Vol. 24, No. 4, 5, 1954.

4) 藤井清光: A Study on Well Spacing, 石技搃， Vol. 24, No. 6, 1959. 